\title{
Selective production of hydrogen peroxide and oxidation of hydrogen sulfide in an unbiased solar photoelectrochemical cell
}

Zong, Xu; Chen, Hongjun; Seger, Brian; Pedersen, Thomas; Dargusch, Matthew S.; McFarland, Eric W.; Li, Can; Wang, Lianzhou

Published in:

Energy \& Environmental Science

Link to article, DOI:

10.1039/C4EE01503G

Publication date:

2014

Document Version

Publisher's PDF, also known as Version of record

Link back to DTU Orbit

Citation (APA):

Zong, X., Chen, H., Seger, B., Pedersen, T., Dargusch, M. S., McFarland, E. W., Li, C., \& Wang, L. (2014). Selective production of hydrogen peroxide and oxidation of hydrogen sulfide in an unbiased solar photoelectrochemical cell. Energy \& Environmental Science, 7(10), 3347-3351.

https://doi.org/10.1039/C4EE01503G

\section{General rights}

Copyright and moral rights for the publications made accessible in the public portal are retained by the authors and/or other copyright owners and it is a condition of accessing publications that users recognise and abide by the legal requirements associated with these rights.

- Users may download and print one copy of any publication from the public portal for the purpose of private study or research.

- You may not further distribute the material or use it for any profit-making activity or commercial gain

- You may freely distribute the URL identifying the publication in the public portal 


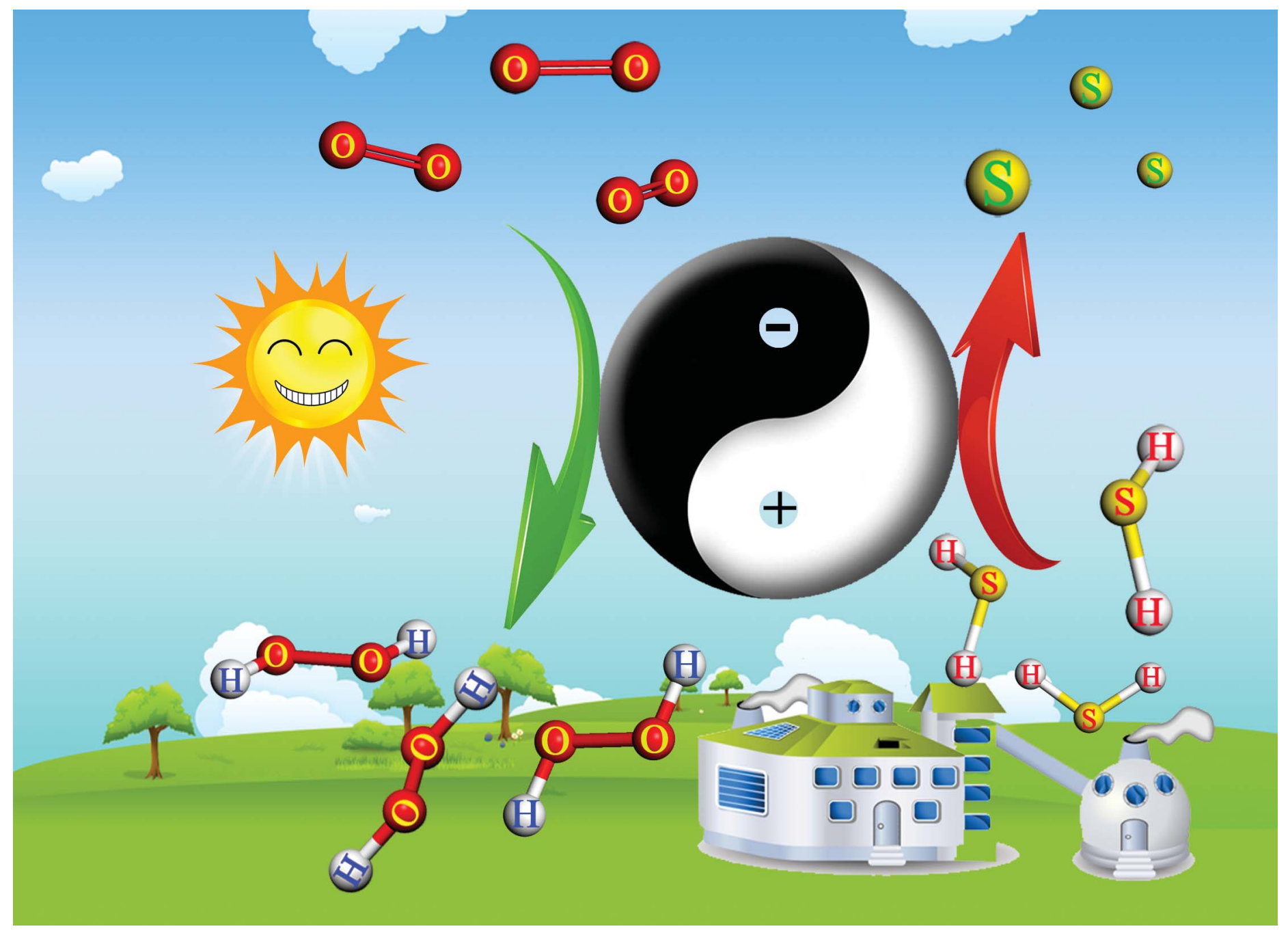

Showcasing research from the collaborative team of Lianzhou Wang from the University of Queensland, Australia, and Can Li from Chinese Academy of Sciences.

Title: Selective production of hydrogen peroxide and oxidation of hydrogen sulfide in an unbiased solar photoelectrochemical cell

Identifying processes capable of producing valuable chemicals by using waste products is significant. This work introduces a dual-functional solar-to-chemical approach which can convert toxic hydrogen sulfide $\left(\mathrm{H}_{2} \mathrm{~S}\right)$ to simultaneously produce valuable hydrogen peroxide $\left(\mathrm{H}_{2} \mathrm{O}_{2}\right)$ and elemental sulfur.

\section{As featured in:}

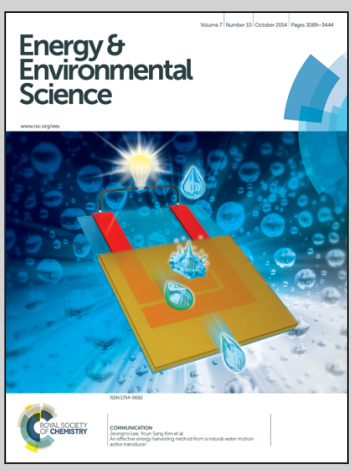

See Can Li, Lianzhou Wang et al., Energy Environ. Sci., 2014, 7, 3347. 


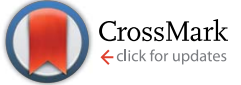

Cite this: Energy Environ. Sci., 2014, 7, 3347

\title{
Selective production of hydrogen peroxide and oxidation of hydrogen sulfide in an unbiased solar photoelectrochemical cell $\dagger$
}

\author{
Xu Zong, ${ }^{\text {ab }}$ Hongjun Chen, ${ }^{a}$ Brian Seger, ${ }^{c}$ Thomas Pedersen, ${ }^{d}$ Matthew S. Dargusch, ${ }^{e}$ \\ Eric W. McFarland, ${ }^{f}$ Can Li ${ }^{* b}$ and Lianzhou Wang ${ }^{* a}$
}

Received 15th May 2014

Accepted 4th August 2014

A solar-to-chemical conversion process is demonstrated using a photoelectrochemical cell without external bias for selective oxidation of hydrogen sulfide $\left(\mathrm{H}_{2} \mathrm{~S}\right)$ to produce hydrogen peroxide $\left(\mathrm{H}_{2} \mathrm{O}_{2}\right)$ and

DOI: $10.1039 / c 4 e e 01503 g$ sulfur (S). The process integrates two redox couples anthraquinone/anthrahydroquinone and $\mathrm{I}^{-} / \mathrm{I}_{3}^{-}$, and

www.rsc.org/ees conceptually illustrates the remediation of a waste product for producing valuable chemicals.

\section{Broader context}

Identifying cost-effective processes for use of solar energy is challenging. Production solely of low-value fuels such as hydrogen necessitates extremely low capital cost systems that have been yet to be identified. Demonstrating a dual-function solar-to-chemical process making higher value chemicals from photogenerated electrons and consuming negative value waste products with the holes can significantly improve the economic sustainability of the process. In this work, we demonstrate a combined photoelectrochemical cell for the remediation of toxic hydrogen sulfide $\left(\mathrm{H}_{2} \mathrm{~S}\right)$ and the production of valuable hydrogen peroxide $\left(\mathrm{H}_{2} \mathrm{O}_{2}\right)$. Moreover, we highlight the importance of fine-tuning the selectivity of photochemical reactions by using well-designed transformation processes.

The efficient transformation of solar energy into important products and fuels is essential for the realization of a solar energy economy. ${ }^{\mathbf{1 - 4}}$ Photochemical processes with dual-functions are attractive due to their potential for activating two or more reaction partners in a single photoredox catalytic cycle without the necessity of quenching or sacrificial reagents. ${ }^{5-7}$ This means that the both the photogenerated electron and hole can drive useful redox reactions, therefore making use of the potential energy stored in both carriers.

To utilize a dual-function approach, different strategies can be used to drive useful reactions with the electrons and the holes. In photoelectochemical-photocatalytic water splitting

\footnotetext{
${ }^{a}$ Nanomaterials Centre, School of Chemical Engineering and AIBN, The University of Queensland, QLD 4072, Australia. E-mail: l.wang@uq.edu.au; Fax: +61 7 33654199; Tel: +6173365218

${ }^{b}$ State Key Laboratory of Catalysis, Dalian Institute of Chemical Physics, Chinese Academy of Sciences and Dalian Laboratory for Clean Energy, Dalian 116023, China. E-mail: canli@dicp.ac.cn; Fax: +86 411 84694447; Tel: +86 41184379070 ${ }^{c}$ CINF, Department of Physics, Technical University of Denmark, 2800 Kongens Lyngby, Denmark

${ }^{d}$ Department of Micro- and Nanotechnology, Technical University of Denmark, 2800 Kongens Lyngby, Denmark

${ }^{e}$ Centre for Advanced Materials Processing and Manufacturing, School of Mechanical and Mining Engineering, The University of Queensland, QLD 4072, Australia

${ }^{f} U Q$ 's Dow Centre for Sustainable Engineering Innovation, School of Chemical Engineering and AIBN, The University of Queensland, QLD 4072, Australia

$\dagger$ Electronic supplementary information (ESI) available: Experimental details, reaction scheme, PEC measurements, characterizations. See DOI: 10.1039/c4ee01503g
}

reactions, $\mathrm{H}_{2}$ and $\mathrm{O}_{2}$ are directly produced simultaneously. ${ }^{\mathbf{8 - 1 1}}$ An indirect strategy is to store solar energy in intermediate species and then use the intermediate species to drive the subsequent reactions. ${ }^{7}$ In many cases, this indirect pathway is kinetically more favourable and therefore more easily implemented. Moreover, an indirect pathway may make the reaction choice more flexible and potentially produce commercially valuable products with high selectivity. We have investigated the dual-function approach to achieve efficient solar energy transformation for target reactions with potentially useful and valuable products.

As is well-known, hydrogen peroxide $\left(\mathrm{H}_{2} \mathrm{O}_{2}\right)$ is an important commodity oxidant. ${ }^{\mathbf{1 2}, 13}$ It is currently produced by an anthraquinone (AQ) process, in which hydrogenation of AQ with $\mathrm{H}_{2}$ produces anthrahydroquinone $\left(\mathrm{H}_{2} \mathrm{AQ}\right)$ and subsequent oxidation of $\mathrm{H}_{2} \mathrm{AQ}$ by $\mathrm{O}_{2}$ produces $\mathrm{H}_{2} \mathrm{O}_{2}$ (Scheme $\left.\mathrm{S} 1 \dagger\right) .{ }^{14}$ As an alternative to this process, photochemical reduction of $\mathrm{O}_{2}$ to produce $\mathrm{H}_{2} \mathrm{O}_{2}$ is attractive for production of $\mathrm{H}_{2} \mathrm{O}_{2}$ as a chemical product or fuel. ${ }^{15-17}$ Moreover, the production of valuable and easilystorable hydrogen peroxide using a photochemical reaction may avoid the costs and safety concerns of processes using $\mathrm{H}_{2}$.

Enormous quantities of $\mathrm{H}_{2} \mathrm{~S}$ are a byproduct of oil and gas production. It is toxic and expensive to manage. At present, $\mathrm{H}_{2} \mathrm{~S}$ is primarily treated using the Claus process wherein it is partially oxidized by $\mathrm{O}_{2}$ to yield $\mathrm{S}$ and $\mathrm{H}_{2} \mathrm{O} .{ }^{18}$ A solar-to-chemical process to selectively convert $\mathrm{H}_{2} \mathrm{~S}$ and $\mathrm{O}_{2}$ into $\mathrm{S}$ and $\mathrm{H}_{2} \mathrm{O}_{2}$ (instead of $\mathrm{H}_{2} \mathrm{O}$ ), may have both economic and environmental benefits. 
In this study, we coupled two separate photoelectrochemicalchemical reaction systems: reduction of $\mathrm{O}_{2}$ with anthrahydroquinone $\left(\mathrm{H}_{2} \mathrm{AQ}\right)$ to produce hydrogen peroxide $\left(\mathrm{H}_{2} \mathrm{O}_{2}\right)$ and anthraquinone (AQ) which is electro-reduced to $\mathrm{H}_{2} \mathrm{AQ}$, and oxidation of hydrogen sulfide $\left(\mathrm{H}_{2} \mathrm{~S}\right)$ to elemental sulfur $(\mathrm{S})$ with $\mathrm{I}_{3}{ }^{-}$produced by photooxidation of $\mathrm{I}^{-}$. To the best of our knowledge, this is the first reported photochemical approach that integrates selective $\mathrm{H}_{2} \mathrm{~S}$ oxidation and $\mathrm{O}_{2}$ reduction reactions to produce hydrogen peroxide.

The approach of selectively converting $\mathrm{H}_{2} \mathrm{~S}$ and $\mathrm{O}_{2}$ to $\mathrm{S}$ and $\mathrm{H}_{2} \mathrm{O}_{2}$ is shown in Scheme 1 and Scheme $\mathrm{S} 2 . \dagger$ The overall reaction consists of two integrated photoelectrochemical-chemical cycles occurring in the anodic and cathodic compartments separated by a Nafion membrane. Every cycle comprises one chemical and one photoelectrochemical reaction.

In the cycle occurring in the anodic compartment, $\mathrm{H}_{2} \mathrm{~S}$ is trapped and selectively oxidized to elemental sulfur and protons through a simple redox reaction (1.1 in Scheme 1) where the conversion of $\mathrm{I}_{3}{ }^{-}$to $\mathrm{I}^{-}$is the corresponding reduction reaction.

Subsequently, the resulting $\mathrm{I}^{-}$is restored to $\mathrm{I}_{3}{ }^{-}$by the photogenerated holes during the photoelectrochemical reaction (1.2). The use of $\mathrm{I}^{-} / \mathrm{I}_{3}{ }^{-}$redox couples will ensure the efficient oxidation of $\mathrm{H}_{2} \mathrm{~S}$, which is superior to the direct oxidation of $\mathrm{H}_{2} \mathrm{~S}$ on the electrode surface due to the mass transfer issue.

In the cycle occurring in the cathodic compartment, $\mathrm{H}_{2} \mathrm{O}_{2}$ is produced through a simple chemical reaction between $\mathrm{H}_{2} \mathrm{AQ}$ and $\mathrm{O}_{2}$ (2.1). The $\mathrm{H}_{2} \mathrm{AQ}$ is oxidized to AQ (Scheme S3†), which is subsequently transformed to $\mathrm{H}_{2} \mathrm{AQ}$ by the photogenerated electrons and the residual protons from oxidation of $\mathrm{H}_{2} \mathrm{~S}$ (2.2).

By integrating the two cycles linked by $\mathrm{I}^{-} / \mathrm{I}_{3}{ }^{-}$and $\mathrm{AQ} / \mathrm{H}_{2} \mathrm{AQ}$ redox couples, the net reaction is the production of $\mathrm{S}$ and $\mathrm{H}_{2} \mathrm{O}_{2}$ from $\mathrm{H}_{2} \mathrm{~S}$ and $\mathrm{O}_{2}$ using solar energy. It is worth noting that $\mathrm{I}^{-} / \mathrm{I}_{3}{ }^{-}$and $\mathrm{AQ} / \mathrm{H}_{2} \mathrm{AQ}$ redox species are negatively charged and won't diffuse through the Nafion membrane. Therefore, the individual redox couples are confined within the anodic and cathodic compartments, respectively, which will prohibit the backward reaction and allow for the separation of the final products. To further clarify the engineering challenges for potentially implementing the concept in a real practice, a more detailed flow-stream design (Scheme S4†) of the reaction processes is presented in Scheme S4. $\dagger$ In this regard, Scheme 1 can be considered as a simplified format of Scheme S4. $\dagger$

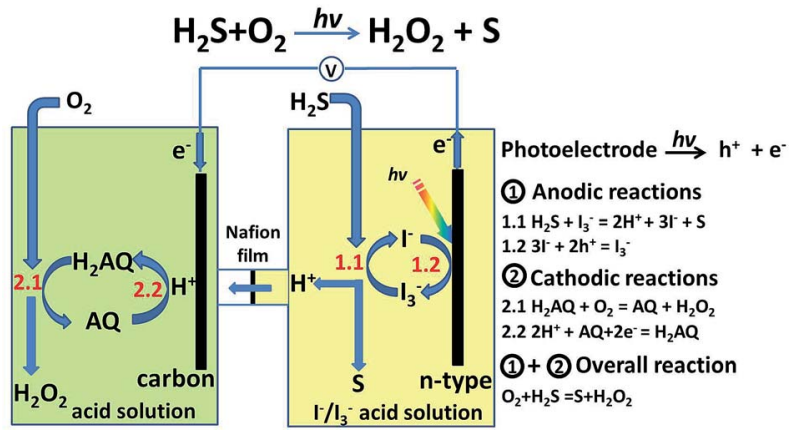

Scheme 1 Schematic illustration on the selective production of $\mathrm{H}_{2} \mathrm{O}_{2}$ and $\mathrm{S}$ from $\mathrm{O}_{2}$ and $\mathrm{H}_{2} \mathrm{~S}$ on $\mathrm{n}$-type electrode.
As a proof of concept, we investigated the cathodic and anodic sides of the reactions on p-type $\mathrm{Si}$ (p-Si) or n-type $\mathrm{Si}(\mathrm{n}$-Si) in a three electrode system, respectively (Fig. S1, experimental details in the ESI $\dagger) .{ }^{\mathbf{1 9 2 0}}$ As shown in Fig.1a, an onset potential of $-0.1 \mathrm{~V} v s$. reversible hydrogen electrode (RHE) was obtained in an acidic AQ electrolyte on $\mathrm{p}-\mathrm{Si}$, which is approximately $0.25 \mathrm{~V}$ more positive than the value obtained in $\mathrm{H}_{2} \mathrm{SO}_{4}$. This indicates the $A Q$ reduction to $\mathrm{H}_{2} \mathrm{AQ}$ is more favorable relative to proton reduction to $\mathrm{H}_{2}$. At an applied potential of $-0.3 \mathrm{~V} v s$. NHE, most of the photocurrent obtained can be ascribed to the reduction of AQ to $\mathrm{H}_{2} \mathrm{AQ}$ instead of proton reduction (Fig. S2 $\dagger$ ). This ensures the high selectivity toward $\mathrm{H}_{2} \mathrm{O}_{2}$ production instead of $\mathrm{H}_{2}$ generation. Moreover, the onset potential for AQ reduction was further notably shifted to $c a$. $0.2 \mathrm{~V} v s$. NHE on the $\mathrm{TiO}_{2} / \mathrm{Ti} / \mathrm{n}^{+} \mathrm{p}-\mathrm{Si}$ electrode due to the extra potential afforded by the surface $\mathrm{n}^{+}$ doping and the possible beneficial effect of $\mathrm{Ti} / \mathrm{TiO}_{2}$ coating for photoelectrochemical reactions. ${ }^{19,20}$

The results of the chronoamperometry showed that the $\mathrm{TiO}_{2} /$ $\mathrm{Ti} / \mathrm{n}^{+} \mathrm{p}$-Si electrode's performance decreased quickly initially, but remained comparatively stable after prolonged testing (Fig. 1b). During chronoamperometry, the AQ solution in the cathodic compartment gradually changed from light yellow to dark green, indicating the generation of $\mathrm{H}_{2} \mathrm{AQ}$ (Fig. S3 $\dagger$ ). This partially led to the decreased activity observed on $\mathrm{TiO}_{2} / \mathrm{Ti} / \mathrm{n}^{+} \mathrm{p}-\mathrm{Si}$ due to the blocking of light by $\mathrm{H}_{2} \mathrm{AQ}$. The solution can be restored to the original yellow colour rapidly when sparged with air, due to the rapid auto-oxidation of $\mathrm{H}_{2} \mathrm{AQ}$ to $\mathrm{H}_{2} \mathrm{O}_{2}$ and $\mathrm{AQ}$ according to Scheme S3. $\uparrow$ Therefore, the energy from photogenerated electrons can be stored as chemical potential energy in the form of $\mathrm{H}_{2} \mathrm{AQ}$ and then liberated to reduce $\mathrm{O}_{2}$ to produce
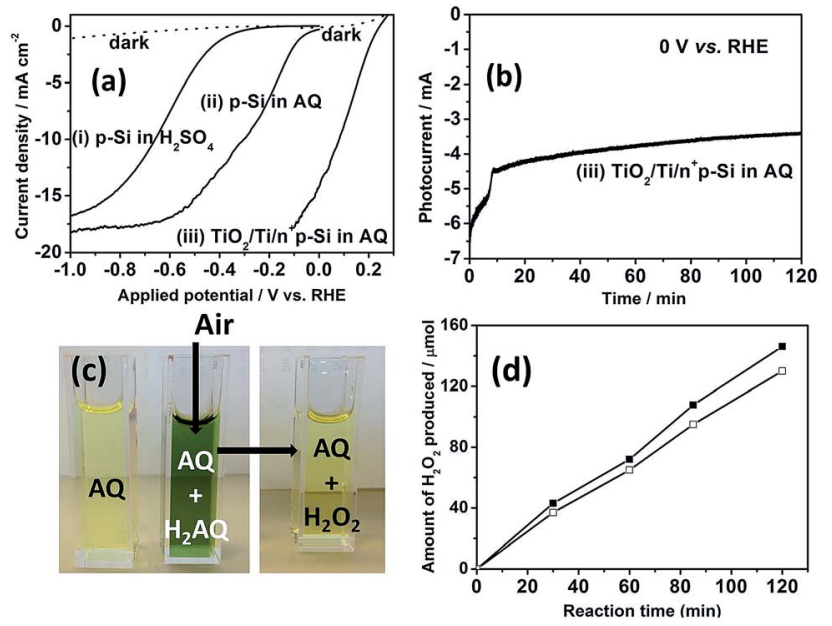

Fig. 1 (a) Current-potential curves of (i) $\mathrm{p}$-Si in $0.5 \mathrm{M} \mathrm{H}_{2} \mathrm{SO}_{4}$ solution, (ii) $\mathrm{p}-\mathrm{Si}$ in saturated $\mathrm{AQ}$ acidic solution, and (iii) $\mathrm{TiO}_{2} / \mathrm{Ti} / \mathrm{n}^{+} \mathrm{p}-\mathrm{Si}$ in saturated $A Q$ acidic solution. (b) Chronoamperometry on $\mathrm{TiO}_{2} / \mathrm{Ti} / \mathrm{n}^{+} \mathrm{p}$ $\mathrm{Si}$ in $\mathrm{AQ}$ acidic solution. (c) Picture showing the generation of $\mathrm{H}_{2} \mathrm{O}_{2}$ after bubbling air into aqueous solution containing $\mathrm{H}_{2} \mathrm{AQ}$ in the middle cuvette. (d) Time course of $\mathrm{H}_{2} \mathrm{O}_{2}$ evolution. Solid squares resemble the calculated amount based upon the charges and the open squares represent the amount measured. Light source: AM1.5G, $100 \mathrm{~mW} \mathrm{~cm}$. A three electrode system was used during the measurement and $0.5 \mathrm{M}$ $\mathrm{H}_{2} \mathrm{SO}_{4}$ was used in the anodic compartment. The surface area of $\mathrm{p}-\mathrm{Si}$ is ca. $1.2 \mathrm{~cm}^{-2}$ and that of $\mathrm{TiO}_{2} / \mathrm{Ti} / \mathrm{n}^{+} \mathrm{p}-\mathrm{Si}$ is ca. $0.5 \mathrm{~cm}^{-2}$. 
$\mathrm{H}_{2} \mathrm{O}_{2}$. The amount of $\mathrm{H}_{2} \mathrm{O}_{2}$ produced gradually increased with the reaction time. The Faradaic efficiency was calculated to be ca. $90 \%$ (Fig. 1d).

We investigated the anodic reactions on functionalized $\mathrm{Pt} /$ $\mathrm{p}^{+} \mathrm{n}$-Si electrode. The $\mathrm{p}^{+}$doping of the $\mathrm{n}$-Si electrode allows for increased photovoltage for the oxidation reaction. Deposition of a Pt catalyst film can protect the Si underneath as well as catalyze $\mathrm{I}^{-}$oxidation to $\mathrm{I}_{3}{ }^{-}$. As shown in Fig. 2a, Pt/p ${ }^{+} \mathrm{n}-\mathrm{Si}$ electrode showed an onset potential of $-0.2 \mathrm{~V} v$ s. RHE and delivered a photocurrent of $c a .12 \mathrm{~mA} \mathrm{~cm}^{-2}$ at an applied potential of as low as $0 \mathrm{~V} v s$. RHE in an acidic KI electrolyte. These values are outstanding compared with our previous functionalized n-Si electrode which showed a more cathodic onset potential of $0.1 \mathrm{~V}$ vs. RHE. $^{7}$ Moreover, the $\mathrm{Pt} / \mathrm{p}^{+} \mathrm{n}-\mathrm{Si}$ electrode showed greater stability during chronoamperometry (Fig. 2b).

During chronoamperometry, the KI solution in the anodic compartment gradually changed to red, indicating the generation of $\mathrm{I}_{3}{ }^{-}$(middle cuvette of Fig. 2c). This corresponds well with the UV-Vis analysis of the reaction solution (Fig. S4†). The enhanced absorption with accumulative $\mathrm{I}_{3}{ }^{-}$could also lead to reduced activity on $\mathrm{Pt} / \mathrm{p}^{+} \mathrm{n}-\mathrm{Si}$ as observed on $\mathrm{TiO}_{2} / \mathrm{Ti} / \mathrm{n}^{+} \mathrm{p}-\mathrm{Si} . \mathrm{H}_{2} \mathrm{~S}$ was bubbled into the solution containing $\mathrm{I}_{3}{ }^{-}$and the solution rapidly changed to a turbid yellow. The yellow precipitate was identified to be $\alpha$-S using X-ray diffraction (XRD) analysis (Fig. S5 $\dagger$ ). The energy from photogenerated holes can thus be stored as chemical potential energy in the form of $\mathrm{I}_{3}{ }^{-}$and then discharged by chemically oxidizing $\mathrm{H}_{2} \mathrm{~S}$ to $\mathrm{S}$ and protons. The amount of $\mathrm{I}_{3}{ }^{-}$produced increased with the reaction time and the Faradaic efficiency was calculated to be greater than $90 \%$ (Fig. 2d).
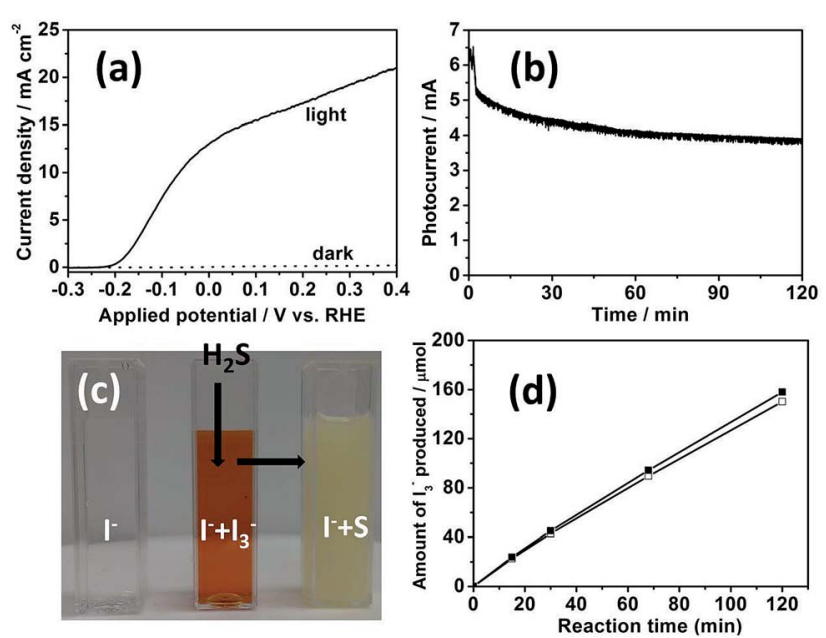

Fig. 2 (a) Current-potential and (b) chronoamperometry curves on $\mathrm{Pt} / \mathrm{p}^{+} \mathrm{n}-\mathrm{Si}$ in $0.1 \mathrm{M} \mathrm{KI}$ acidic solution at an applied potential of $0 \mathrm{~V} v \mathrm{v}$. RHE. (c) Picture showing the generation of $\mathrm{S}$ after bubbling $\mathrm{H}_{2} \mathrm{~S}$ into aqueous solution containing $\mathrm{I}_{3}{ }^{-}$in the middle cuvette. (d) Time course of $\mathrm{I}_{3}{ }^{-}$evolution. Solid squares represent the calculated amount based upon the charges and the open squares resemble the amount measured. Light source: AM1.5G, $100 \mathrm{~mW} \mathrm{~cm}^{-2}$. A three electrode system was used during the measurement and $0.5 \mathrm{M} \mathrm{H}_{2} \mathrm{SO}_{4}$ was used in the cathodic compartment. The surface area of $\mathrm{Pt} / \mathrm{p}^{+} \mathrm{n}-\mathrm{Si}$ is ca. $0.5 \mathrm{~cm}^{-2}$
After separately verifying the cathodic and anodic reactions in three electrode systems, we investigated the integration of the two photoelectrochemical-chemical reaction pairs in a single two electrode system. Single photoelectrodes in the anodic (for $\mathrm{n}-\mathrm{Si}$ ) or cathodic (for $\mathrm{p}-\mathrm{Si}$ ) compartments were used as the light absorber. As shown in Fig. S6a, $\uparrow$ p-Si showed a negligible photocurrent at negative applied bias when using AQ and $\mathrm{H}_{2} \mathrm{SO}_{4}$ in the cathodic and anodic compartments, respectively. However, the photocurrent increased significantly when KI was added to the $\mathrm{H}_{2} \mathrm{SO}_{4}$ in the anodic compartment. The photocurrent and onset potential for $\mathrm{AQ}$ reduction was further improved on the $\mathrm{TiO}_{2} / \mathrm{Ti} / \mathrm{n}^{+} \mathrm{p}-\mathrm{Si}$ electrode (Fig. 3b). As $\mathrm{I}^{-}$ oxidation is thermodynamically more favorable than water oxidation, the use of $\mathrm{KI}$ can relieve the stringent requirement on the anodic side. However, $\mathrm{TiO}_{2} / \mathrm{Ti} / \mathrm{n}^{+} \mathrm{p}$-Si only delivered a negligible photocurrent at zero applied bias. As the conduction band level of $\mathrm{p}$-Si is higher than what is required for AQ and protons reductions, this low photocurrent at zero bias should be ascribed to the inefficient oxidation power of the photogenerated holes.

We then tentatively tried $\mathrm{Pt} / \mathrm{p}^{+} \mathrm{n}-\mathrm{Si}$ in a two electrolyte system with the expectation that an unbiased system could be established due to the high oxidation potential afforded by $\mathrm{p}^{+} \mathrm{n}-\mathrm{Si}$. As shown in Fig. 3a, Pt/p $\mathrm{p}^{+} \mathrm{n}$-Si showed a negligible photocurrent at zero bias when using $\mathrm{KI}$ and $\mathrm{H}_{2} \mathrm{SO}_{4}$ in the anodic and cathodic compartments, respectively. However, the photocurrent increased notably to $8 \mathrm{~mA} \mathrm{~cm}{ }^{-2}$ when adding AQ to $\mathrm{H}_{2} \mathrm{SO}_{4}$ in the cathodic compartment (Fig. 3c). The increased current is expected because AQ is more favorably reduced than protons (Fig. 1a). The selectivity for the $\mathrm{H}_{2} \mathrm{AQ}$ production is calculated to be $c a .98 \%$ by comparing the photocurrent shown in Fig. 1a and
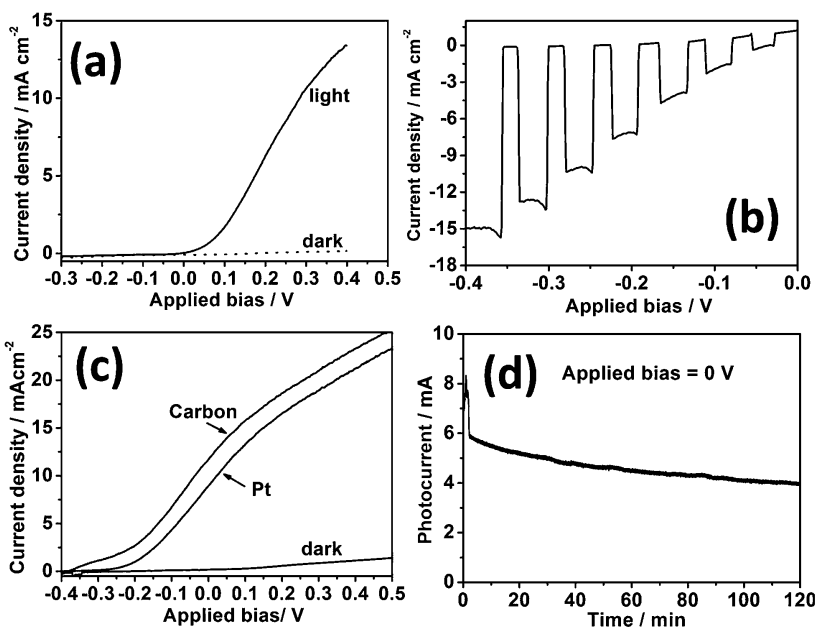

Fig. 3 Bias current-voltage curves in a two electrode system on $(a-c)$ $\mathrm{Pt} / \mathrm{p}^{+} \mathrm{n}-\mathrm{Si}$, and (b) $\mathrm{TiO}_{2} / \mathrm{Ti} / \mathrm{n}^{+} \mathrm{p}$-Si electrodes. During the measurement, (a) $\mathrm{KI}$ and $\mathrm{H}_{2} \mathrm{SO}_{4}$, (b and c) $\mathrm{KI}$ and $\mathrm{AQ}$ were used in the anodic and cathodic compartments, respectively. Pt was used as the counter electrode in $(\mathrm{a}-\mathrm{c})$. Carbon was also tested as the counter electrode in (c). (d) Chronoamperometry at zero bias on $\mathrm{Pt} / \mathrm{p}^{+} \mathrm{n}-\mathrm{Si}$ electrode in two electrode system. The cathodic compartment contained saturated $A Q$ in $0.5 \mathrm{M} \mathrm{H}_{2} \mathrm{SO}_{4}$ and the anodic compartment contained $0.1 \mathrm{M} \mathrm{KI}$ in $0.5 \mathrm{M} \mathrm{H}_{2} \mathrm{SO}_{4}$. The surface area of $\mathrm{Pt} / \mathrm{p}^{+} \mathrm{n}-\mathrm{Si}$ and $\mathrm{TiO}_{2} / \mathrm{Ti} / \mathrm{n}^{+} \mathrm{p}-\mathrm{Si}$ is ca. $0.5 \mathrm{~cm}^{-2}$. 
c. Taking the solar energy stored in the form of $\mathrm{I}_{3}{ }^{-}$and $\mathrm{H}_{2} \mathrm{AQ}$ during reactions 1.2 and 2.2 (Scheme 1) into consideration, the solar-to-chemical conversion efficiency was estimated to be $c a$. $1.1 \%$. Therefore, by using $\mathrm{KI}$ and $\mathrm{AQ}$ as the electrolyte, $\mathrm{Pt} / \mathrm{p}^{+} \mathrm{n}-\mathrm{Si}$ can affect the simultaneous oxidation of $\mathrm{I}^{-}$to $\mathrm{I}_{3}{ }^{-}$and the reduction of $\mathrm{AQ}$ to $\mathrm{H}_{2} \mathrm{AQ}$ under zero applied bias (Fig. S7 $\dagger$ ). This is due to the fact that the combined use of KI and AQ species in the anodic and cathodic compartments can considerably decrease the potential required to run the photoelectrochemical cell.

When a carbon plate was used as the counter electrode instead of Pt, a negative shift in the onset potential and a higher photocurrent was observed at zero bias possibly due to the more efficient reduction of AQ on the carbon. This has been further testified by cyclic voltammetry on carbon and $\mathrm{Pt}$ electrodes in the presence of acidic AQ electrolyte (Fig. S8 $\dagger$ ). Using carbon to replace Pt would significantly reduce the cost of the system and the overpotential for $\mathrm{H}_{2}$ evolution on carbon is quite high (Fig. S8a $\dagger$ ), thus the use of carbon will ensure the high selectivity toward AQ reduction. $\mathrm{No}_{2}$ was observed in the cathodic compartment by gas chromatography, suggesting the high selectivity to $\mathrm{H}_{2} \mathrm{AQ}$ instead of $\mathrm{H}_{2}$ production. Our results suggest that the energy from the photogenerated electrons and holes can be stored simultaneously in the form of $\mathrm{H}_{2} \mathrm{AQ}$ and $\mathrm{I}_{3}{ }^{-}$redox couples and subsequently released to produce $\mathrm{H}_{2} \mathrm{O}_{2}$ and $\mathrm{S}$ by reaction with $\mathrm{O}_{2}$ and $\mathrm{H}_{2} \mathrm{~S}$. Therefore, integrating the photochemicalchemical reaction pairs, solar energy is continuously driving $\mathrm{S}$ and $\mathrm{H}_{2} \mathrm{O}_{2}$ production while treating $\mathrm{H}_{2} \mathrm{~S}$ with $\mathrm{O}_{2}$.

Recently we reported the direct splitting of $\mathrm{H}_{2} \mathrm{~S}$ to produce $\mathrm{H}_{2}$ and $\mathrm{S}$ using solar energy. ${ }^{7}$ Although the as-produced $\mathrm{H}_{2}$ can be used to produce $\mathrm{H}_{2} \mathrm{O}_{2}$ through the traditional AQ process, unbiased production of $\mathrm{H}_{2}$ was not demonstrated. However, using the more thermodynamically favourable reduction of $\mathrm{AQ}$ instead of protons, we can generate $\mathrm{H}_{2} \mathrm{O}_{2}$ selectively at zero bias without producing $\mathrm{H}_{2}$. The present approach represents a potentially more efficient and safer route for the production of $\mathrm{H}_{2} \mathrm{O}_{2}$ and $\mathrm{S}$ from $\mathrm{O}_{2}$ and $\mathrm{H}_{2} \mathrm{~S}$.

We also note that the onset potential for $A Q$ reduction on the p-Si photocathode is much higher than expected. For example, the onset potential for proton reduction on $\mathrm{Pt} / \mathrm{TiO}_{2} /$ $\mathrm{Ti} / \mathrm{n}^{+} \mathrm{p}-\mathrm{Si}$ is $0.5 \mathrm{~V}$ vs. RHE, while that for $\mathrm{AQ}$ reduction on $\mathrm{TiO}_{2} / \mathrm{Ti} / \mathrm{n}^{+} \mathrm{p}-\mathrm{Si}$ is only $0.2 \mathrm{~V} v s$. NHE even though AQ is more easily reduced than protons. We ascribed this observation to the lack of a suitable catalyst for $\mathrm{TiO}_{2} / \mathrm{Ti} / \mathrm{n}^{+} \mathrm{p}-\mathrm{Si}$. As the loading of a suitable cocatalyst can significantly improve rates, it is anticipated that the AQ reduction reaction could be promoted by employing a suitable catalyst. ${ }^{19-22}$ Moreover, even deactivation is observed on $\mathrm{Pt} / \mathrm{p}^{+} \mathrm{n}-\mathrm{Si}$ during the reactions (Fig. 3d), it is possible to further improve its performance by a structural modification or by optimizing the coating process. ${ }^{23-25}$ These efforts might enable an efficient system for the unbiased production of $\mathrm{H}_{2} \mathrm{O}_{2}$ and $\mathrm{S}$ by treating $\mathrm{H}_{2} \mathrm{~S}$. However, to make this concept commercially viable, we should not underestimate the technological challenges including the long-term stability issue.

\section{Conclusions}

A solar-driven process which requires no external bias is demonstrated with the dual-function of selective production of $\mathrm{H}_{2} \mathrm{O}_{2}$ and $\mathrm{S}$ from $\mathrm{O}_{2}$ and $\mathrm{H}_{2} \mathrm{~S}$. By combining the AQ/AQH $\mathrm{H}_{2}$ and $\mathrm{I}^{-} / \mathrm{I}_{3}{ }^{-}$redox couples, the indirect photoreduction of $\mathrm{O}_{2}$ to $\mathrm{H}_{2} \mathrm{O}_{2}$ and photooxidation of $\mathrm{H}_{2} \mathrm{~S}$ to $\mathrm{S}$ were integrated to achieve a photochemical-chemical cycle with an overall efficiency of $1.1 \%$. This work not only demonstrates an innovative route for the environmental remediation of toxic and abundant $\mathrm{H}_{2} \mathrm{~S}$ and the simultaneous generation of a valuable chemical product but also highlights the importance of tuning the selectivity of photochemical reactions by using well-designed transformation processes.

\section{Acknowledgements}

This project was supported by Australian Research Council (through its DP and FT programs), Queensland State Government Smart State program (NIRAP) and 973 National Basic Research Program of the Ministry of Science and Technology of China (no. 2014CB239400). This work was performed in part at the QLD node of the Australian National Fabrication Facility. We gratefully acknowledge the Danish Ministry of Science for funding the Catalysis for Sustainable Energy (CASE) initiative and the Danish National Research Foundation for founding The Center for Individual Nanoparticle Functionality (DNRF54).

\section{Notes and references}

1 X. B. Chen, S. H. Shen, L. J. Guo and S. S. Mao, Chem. Rev., 2010, 110, 6503-6570.

2 Z. G. Yi, J. H. Ye, N. Kikugawa, T. Kako, S. X. Ouyang, H. Stuart-Williams, H. Yang, J. Y. Cao, W. J. Luo, Z. S. Li, Y. Liu and R. L. Withers, Nat. Mater., 2010, 9, 559-564.

3 H. J. Yan, J. H. Yang, G. J. Ma, G. P. Wu, X. Zong, Z. B. Lei, J. Y. Shi and C. Li, J. Catal., 2009, 266, 165-168.

4 A. Kudo and Y. Miseki, Chem. Soc. Rev., 2009, 38, 253-278.

5 Y. Q. Zou, J. R. Chen and W. J. Xiao, Angew. Chem., Int. Ed., 2013, 52, 11701-11703.

6 A. McNally, C. K. Prier and D. W. C. MacMillan, Science, 2011, 334, 1114-1117.

7 X. Zong, J. Han, B. Seger, H. Chen, G. Lu, C. Li and L. Wang, Angew. Chem., Int. Ed., 2014, 53, 4399-4403.

8 K. Maeda, K. Teramura, D. Lu, T. Takata, N. Saito, Y. Inoue and K. Domen, Nature, 2006, 440, 295.

9 H. Kato, K. Asakura and A. Kudo,J. Am. Chem. Soc., 2003, 125, 3082-3089.

10 F. F. Abdi, L. Han, A. H. M. Smets, M. Zeman, B. Dam and R. van de Krol, Nat. Commun., 2013, 4, 2195.

11 L. Han, F. F. Abdi, P. P. Rodriguez, B. Dam, R. van de Krol, M. Zeman and A. H. M. Smets, Phys. Chem. Chem. Phys., 2014, 16, 4220-4229.

12 J. K. Edwards, B. Solsona, E. N. Ntainjua, A. F. Carley, A. A. Herzing, C. J. Kiely and G. J. Hutchings, Science, 2009, 323, 1037-1041. 
13 J. H. Lunsford, J. Catal., 2003, 216, 455-460.

14 J. M. Campos-Martin, G. Blanco-Brieva and J. L. G. Fierro, Angew. Chem., Int. Ed., 2006, 45, 6962-6984.

15 H. Goto, Y. Hanada, T. Ohno and M. Matsumura, J. Catal., 2004, 225, 223-229.

16 C. Kormann, D. W. Bahnemann and M. R. Hoffmann, Environ. Sci. Technol., 1988, 22, 798-806.

17 S. Kato, J. U. Jung, T. Suenobu and S. Fukuzumi, Energy Environ. Sci., 2013, 6, 3756-3764.

18 A. Pieplu, O. Saur, J. C. Lavalley, O. Legendre and C. Nedez, Catal. Rev.: Sci. Eng., 1998, 40, 409-450.

19 B. Seger, T. Pedersen, A. B. Laursen, P. C. K. Vesborg, O. Hansen and I. Chorkendorff, J. Am. Chem. Soc., 2013, 135, 1057-1064.
20 B. Seger, A. B. Laursen, P. C. K. Vesborg, T. Pedersen, O. Hansen, S. Dahl and I. Chorkendorff, Angew. Chem., Int. Ed., 2012, 51, 9128-9131.

21 X. Zong, G. P. Wu, H. J. Yan, G. J. Ma, J. Y. Shi, F. Y. Wen, L. Wang and C. Li, J. Phys. Chem. C, 2010, 114, 1963-1968.

22 X. Zong, H. J. Yan, G. P. Wu, G. J. Ma, F. Y. Wen, L. Wang and C. Li, J. Am. Chem. Soc., 2008, 130, 7176-7177.

23 S. Mubeen, J. Lee, N. Singh, M. Moskovits and E. W. McFarland, Energy Environ. Sci., 2013, 6, 1633-1639.

24 T. Yang, H. Wang, X. M. Ou, C. S. Lee and X. H. Zhang, Adv. Mater., 2012, 24, 6199-6203.

25 K. Q. Peng and S. T. Lee, Adv. Mater., 2011, 23, 198-215. 